\title{
Evaluation of Antimicrobial Effects of Four Selected Marine Macroalgae from Iskenderun Bay
}

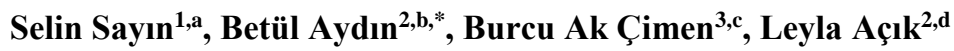 \\ ${ }^{1}$ Department of Marine Technologies, Faculty of Marine Sciences and Technology, Iskenderun Technical University, 31200 Iskenderun, Hatay, Turkey \\ ${ }^{2}$ Department of Biology, Faculty of Science, Gazi University, 06560 Ankara, Turkey \\ ${ }^{3}$ Department of Basic Science, Faculty of Fisheries, Çukurova University, 01330 Adana, Turkey \\ *Corresponding author
}

\begin{tabular}{l|l}
\hline A R T I C L E I N F O & A B S T R A C T \\
\hline $\begin{array}{l}\text { Research Article } \\
\text { Received : 18/06/2021 }\end{array}$ & $\begin{array}{l}\text { In the present study, the seaweeds belong to Phaeophyaceae (Cystoseira elegans Sauvageau 1912, } \\
\text { Cystoseira amentacea (C.Agardh) Bory 1832, Padina crassa Yamada 1931) and Florideophyceae } \\
\text { (Corallina elongata J.Ellis \& Solander 1786) collected from nearby Iskenderun-Turkey of } \\
\text { Mediterranean Sea were detected for their antimicrobial activities against seven bacterial strains } \\
\text { (Escherichia coli ATCC 35218, Bacillus cereus NRRL B-371, Staphylococcus aureus ATCC } \\
\text { 25923, Pseudomonas aeruginosa ATCC 27853, Klebsiella pneumoniae ATCC 13883, Salmonella } \\
\text { typhimurium ATCC 14028, Proteus vulgaris RSKK 96029). The antimicrobial activities were } \\
\text { expressed as minimum inhibitory concentrations (MICs) and minimum bactericidal concentrations } \\
\text { (MBCs). According to the results obtained from MICs and MBCs values of the extracts on } \\
\text { pathogenic microorganisms were between 0.78 to 50 mg/mL. The lowest MICs and MBCs values } \\
\text { were recorded for C. elegans extract against B. cereus with a MIC value of 0.78 mg/mL. These } \\
\text { results suggest that secondary metabolites of brown and red algae are important sources that could } \\
\text { be used as broad spectrum of biological and pharmaceutical activities. }\end{array}$ \\
$\begin{array}{l}\text { Antimicrobial activities } \\
\text { MICs }\end{array}$ &
\end{tabular}

MBCs secondary metabolites

Pharmaceutical activities

selin.sayin@iste.edu.tr

bak@cu.edu.tr https://orcid.org/0000-0002-9092-1350

https://orcid.org/0000-0002-3672-8429

\section{Introduction}

As photosynthetic organisms, algae are the primary producers in aquatic ecosystems with rich biodiversity, especially marine environments. Seaweed, also known as macroalgae, have unique biological activities (Blunt et al., 2007). Seaweeds are divided into broad groups depending on their nutritional and chemical composition, and brown, red or green algae are the main groups. Seaweeds are defined as the main source of bioactive components that can produce a large variety of secondary metabolites distinguished by a wide range of natural biological activities.

Seaweeds have been the subject of numerous studies and many important metabolites such as amino acids, vitamins, proteins, carbohydrates, pigments, terpenoids, lipids, fatty acids, minerals, glycerol, sterols, polysaccharides, tocopherol, phenolic compounds, and halogenated ketones (Mohamed et al., 2012). Secondary metabolites as essential oils, alginic acid, fucoidans, laminarine, fucans, agar, carrageenan, fluorotannines, phloroglucinol, terpenes, organic acids, cellulose, alkaloid, sterol, phenolic, and many other substances are extracted from structural materials in algae cells (Abourriche et al., 1999; Nagayama, 2002; Smith et al., 2002; Ghannadi et al., 2013; Yegdaneh et al., 2016). Various studies have been reported proving that the strong secondary components obtained from extracts of seaweeds species of these metabolites have antioxidant, antimicrobial (Chiheb et al., 2009; Cornish and Garbary 2010; Salem et al., 2011; Tambekar et al., 2011; Mayer et al., 2011; Güner et al. 2015; Silva et al., 2020), antiviral (Musale et al., 2020; Hans et al., 2021), antifungal (Oumaskour et al., 2012; Mickymaray et al., 2018; Biris-Dorhoi et al., 2020), antibiotics (Brana et al.,2015; Bhowmick et al., 2020), antiinflammatory (Kazlowska et al., 2010; Jaswir and Monsur 2011), antiallergic, antihypertensive, antitumor (Güner et al., 2015; Seca and Pinto 2018; Güven et al., 2020; Wang et al., 2020), anticancer (Güner et al., 2019), antifouling (Dahms and Dobretsov, 2017), and 
anticoagulant activities (Adrien et al., 2017). Seaweeds have described as an agent and has been widely used in many areas in many countries, especially China, Japan and India. In addition to its ecological importance, seaweeds are used as raw materials in many areas of the industry, such as food, agriculture, renewable energy, biodiesel, medical, pharmaceutical, nutraceutical, medicine, microbiology, biotechnology, cosmetics, animal feed and fertilizer (Watson et al., 2003; Yuan et al., 2005; Bansemir et al., 2006; Chew et al., 2008; Silva et al., 2020). In recent years, due to the increasing interest in natural product-based foods and medicines, there is more need for studies on this subject in seaweeds with rich content. Considering the side effects, immunization and toxic effects of conventional treatments, especially in cancer treatments, the opportunity to use algae with high antioxidant content, more effective and relatively fewer toxic properties has emerged as alternative applications in this field.

As a consequence of increasing demand in screening for research on the use of algae as antimicrobial agents that inhibit or kill the growth of microorganisms and are used to treat microbial infections. Antimicrobial drugs have been found in the form of antibacterial, antiviral, antifungal and plant-derived bioactive compounds, either synthetic or natural, depending on the microorganisms acting primarily in response to their activities (Pérez et al., 2016). Many seaweed species with bioactive compounds have been shown to inhibit the growth of some gram-negative and gram-positive bacterial pathogens and identified as potential a source of natural antioxidants (Matanjun et al., 2008). The antimicrobial activity of macroalgae is due to chlorophyll derivatives, alkaloids, aminoacids, fatty acids, lipophilic compound, acrylic acid, terpenes, phenolic substances, cyclic polysulfides, steroids, fluorotannines, halogenates (ketones and alkanes), isopyrenoid and sulfur-containing heterocyclic components (Glombitza, 1979; Watson and Cruz-Rivera, 2003; Paul and Puglisi, 2004; Mohamed et al., 2012). Although the functions of secondary products differ, those with cytotoxic effects against microbial pathogens are used as antimicrobial agents in medicine. Considering the research in this field, natural products with biological and pharmacological effects are predominantly species belonging to marine brown, red and green macroalgae (Bhadury and Wright, 2004). Mostly red and brown algae of seaweeds groups have been used as human food resource and traditional medicine since ancient times (Smith, 2004).

The fact that seaweeds species with such intensive use in the world but, few studies on antimicrobial activities of investigation of pharmacological properties of these compounds have been published in our country. Therefore, in this study, the effect of the antimicrobial activities of brown algae Cystoseira elegans Sauvageau 1912 (Phaeophyceae), Cystoseira amentacea (C.Agardh) Bory 1832 (Phaeophyceae), Padina crassa Yamada 1931(Phaeophyceae) and red algae Corallina elongata J.Ellis \& Solander 1786 (Florideophyceae) marine macroalgae collected from the Iskenderun Bay, against pathogenic bacteria were investigated. At the same time, another purpose of the present study is to give direction to future pharmaceutical or nutraceutical uses by comparing algae groups with different secondary metabolites together with the antimicrobial effects of algae.

\section{Materials and Methods}

\section{Macroalgae Species}

Macroalgae species of Cystoseira elegans Sauvageau 1912, Cystoseira amentacea (C.Agardh) Bory 1832, Padina crassa Yamada 1931, Corallina elongata J.Ellis \& Solander 1786 were collected nearby Iskenderun-Turkey of Mediterranean Sea. Macroalgae were washed with distilled water and dried under room temperature. The brown algae Cystoseira elegans and Cystoseira amentacea belongs to Sargassaceae family of Phaeophyceae class and Padina crassa belongs to Dictyotaceae family of Phaeophyceae class. The red algae Corallina elongata belongs to Corallinaceae family of Florideophyceae class. Macroalgae species were presented in Table 1.

\section{Preparation of the Extracts}

The dried algal samples were extracted by maceration in 1:4 (w/v) biomass/solvent ratio with methanol for 2 weeks at room temperature in a dark environment. The obtained methanolic extract was filtered through filter paper. After filtration, the solvent was evaporated at $50^{\circ} \mathrm{C}$ under reduced pressure in a rotary evaporator (Heidolph, Germany), and deposited at $+4{ }^{\circ} \mathrm{C}$ before further usage. For antimicrobial analysis, the extracts were dissolved in DMSO at a concentration of $250 \mathrm{mg} / \mathrm{mL}$ and sterilized by a $0.45 \mathrm{~mm}$ pore sized syringe filter.

\section{Microorganisms and Growth Conditions}

Seven bacterial strains have been used to evaluate the antibacterial activities of the extracts. Bacterial strains were as follows; Escherichia coli ATCC 35218, Bacillus cereus NRRL B-3711, Staphylococcus aureus ATCC 25923, Pseudomonas aeruginosa ATCC 27853, Klebsiella pneumoniae ATCC 13883, Salmonella typhimurium ATCC 14028, Proteus vulgaris RSKK 96029. All bacterial cultures were incubated in Tryptic soy agar at $37^{\circ} \mathrm{C}$ for $24 \mathrm{~h}$.

\section{Broth Microdilution Assay}

The minimum inhibitory concentrations (MICs) of the extracts were evaluated by the broth microdilution assay in 96-well microtitre plates according to CLSI reference methods for bacteria M7-A7 (CLSI, 2018). Antibiotics used as positive controls included Ampicillin and Chloramphenicol. Two-fold serial dilutions of the extracts and antibiotics in mueller hinton broth were made at a concentration range of 50- 0.39 for the extracts and 250-0.98 $\mathrm{mg} / \mathrm{mL}$ for the antibiotics on 96-well microtitre plates. Microorganism inoculums were prepared from a 24-hour culture and suspensions in $0.9 \%$ of $\mathrm{NaCl}$ were adjusted to $0.5 \mathrm{McFarland}\left(1.5 \times 10^{8} \mathrm{cfu} / \mathrm{mL}\right)$ standard turbidity. Five microliters of microorganism suspension have been added to all wells. The microtitre plates were then incubated for $24 \mathrm{~h}$ at $37^{\circ} \mathrm{C}$. After incubation, MIC values of the extracts were Determined by lack of the visual turbidity. The minimum bactericidal concentrations (MBCs) values were determined by subculturing ten microliters volumes from non-turbid wells and spot inoculating onto an appropriate growth medium. After incubation, growth was recorded and MBCs were defined as the lowest concentration resulting in the death of $99.9 \%$ of the inoculum compared to the initial viable counts. The assay was repeated at least three times and the average values of MICs and MBCs were selected. 
Table 1. Seaweed species which were used in this study

\begin{tabular}{l|c}
\hline \multicolumn{1}{c|}{ Seaweed species } & Class \\
\hline Cystoseira elegans Sauvageau 1912 & Phaeophyceae \\
Cystoseira amentacea (C.Agardh) Bory 1832 & Phaeophyceae \\
Padina crassa Yamada 1931 & Phaeophyceae \\
Corallina elongata J.Ellis \& Solander 1786 & Florideophyceae \\
\hline
\end{tabular}

Table 2. Minimum inhibitory concentration (MIC) values of the macroalgae species extracts $(\mathrm{mg} / \mathrm{mL})$

\begin{tabular}{l|cccccc}
\hline \multirow{2}{*}{ Microorganisms } & \multicolumn{3}{|c}{ Macroalgae Species } & \multicolumn{2}{c}{ Positive controls } \\
\cline { 2 - 7 } & Cystoseira elegans & Cystoseira amentaceaPadina crassaCorallina elongataAmpicillin Chloramphenicol \\
\hline E. coli & 50 & 50 & 50 & 25 & $>125$ & $>125$ \\
B. cereus & 0.78 & 3.13 & 6.25 & 1.56 & 31.25 & 125 \\
S. aureus & 6.25 & 12.5 & 12.5 & 3.13 & 62.5 & 125 \\
P. aeruginosa & 12.5 & 12.5 & 12.5 & 6.25 & $>125$ & $>125$ \\
K. pneumoniae & 12.5 & 12.5 & 12.5 & 3.13 & 125 & 15.63 \\
S. typhimurium & 50 & 50 & 50 & 50 & 62.5 & 125 \\
P. vulgaris & 25 & 25 & 25 & 25 & $>125$ & 125 \\
\hline
\end{tabular}

Table 3. Minimum bactericidal concentration (MBC) values of the macroalgae species extracts $(\mathrm{mg} / \mathrm{mL})$

\begin{tabular}{l|cccccc}
\hline \multirow{2}{*}{ Microorganisms } & \multicolumn{3}{|c}{ Macroalgae Species Extracts } & \multicolumn{2}{c}{ Positive controls } \\
\cline { 2 - 7 } & Cystoseira elegans & Cystoseira amentaceaPadina crassaCorallina elongataAmpicillinChloramphenicol \\
\hline E. coli & 50 & 50 & 50 & 50 & $>125$ & $>125$ \\
B. cereus & 0.78 & 3.13 & 25 & 12.5 & $>125$ & 125 \\
S. aureus & 6.25 & 25 & $>50$ & 6.25 & 62.5 & $>125$ \\
P. aeruginosa & 12.5 & 12.5 & 1.56 & 6.25 & $>125$ & $>125$ \\
K. pneumoniae & 50 & 50 & 50 & 12.5 & 125 & 15.63 \\
S. typhimurium & 50 & 50 & 50 & 50 & 62.5 & 125 \\
P. vulgaris & 25 & 25 & 25 & 25 & $>125$ & $>125$ \\
\hline
\end{tabular}

\section{Results and Discussion}

Extracts of macroalgae species (Cystoseira elegans, Cystoseira amentacea, Padina crassa, Corallina elongata) were tested against seven bacteria (Escherichia coli, Bacillus cereus, Staphylococcus aureus, Pseudomonas aeruginosa, Klebsiella pneumoniae, Salmonella typhimurium, Proteus vulgaris). MICs and MBCs values of four seaweed extracts on tested pathogen bacteria are given in Table 2 and Table 3, respectively. Depending on the results obtained, the MICs and MBCs values vary from 0.78 to $50 \mathrm{mg} / \mathrm{mL}$. All extracts have a significant bactericidal and bacteriostatic effect on the studied bacteria.

According to the results obtained from the present study, among the tested bacteria, extracts demonstrated the strongest antimicrobial effect on B. cereus. The lowest MIC and MBC values were recorded for $C$. elegans extract against $B$. cereus with a MIC value of $0.78 \mathrm{mg} / \mathrm{mL}$ (Table $2)$. Besides, this value was even lower than that of Ampicillin and Chloramphenicol antibiotics used as positive controls. In addition, all extracts used in the study had better antimicrobial effects on E. coli, B. cereus, $S$. aureus, $P$. aeruginosa, K. pneumoniae, S. typhimurium and P. vulgaris than Ampicillin and Chloramphenicol antibiotics.

As Tables 2 and 3 presented, all extracts have antimicrobial effects against the tested macroalgae species. Among the seaweed species used in this study, Cystoseira elegans, Cystoseira amentacea, Padina crassa, Corallina elongate have been determined antimicrobial activity were tested against seven bacteria. According to previous studies, results similar to antimicrobial effects were obtained in this study (Smith 2004; Gouveia et al., 2013; El Shafay et al., 2016; Jegan et al., 2019).

Tuney et al. (2006) obtained that the diethyl ether extracts of Cystoseira mediterranea have antimicrobial activity against $E$. coli, E. faecalis and $P$. aeruginosa and have antifungal activity against Candida sp. In previous study, researchers evaluated the antimicrobial activity of the seaweeds in Turkey. They determined that among the seaweed species used in this study, Cystoseria compressa have shown an excellent antimicrobial activity against pathogen bacteria (Dulger et al., 2009). In another study, Salvador et al. (2007) reported that 82 different marine macroalgae classified the among the selected taxa of brown algae as known Phaeophyceae were determined that the most effective antimicrobial activity.

Manivannan et al. (2011) revealed that different solvent extracts obtained from Turbinaria conoides, Padina gymnospora, and Sargassum tenerrimum brown algae showed significant antibacterial activity. Besides, it was observed that the antimicrobial activity of compounds from Himanthalia elongata, Laminaria digitata and Laminaria saccharina and several other algae species varied according to the solvent used, and methanol extract from brown algae had better results in comparison to acetone extract from green and red algae (Cox et al., 2010). Hence, in this study were investigated to screen and evaluate the efficiency of methanol extracts of Cystoseira elegans, Cystoseira amentacea, Padina crassa, Corallina elongata as antimicrobial activities. In another previous study; methanol extracts of 26 marine algae collected from the Mediterranean coasts were found to show strong and moderate activity against 3 gram-positive (E. faecalis) and 
2 gram-negative (E. coli, Klebsiella $\mathrm{sp}$.) bacterial strains (Rhimou et al., 2010). In another study conducted with 32 algae species collected from Pakistani Karaci, researcher reported that almost all algae show different levels of antimicrobial activity against common gram-positive and gram-negative strains in humans, animals and plants (Rizvi and Shammel, 2004). Divya et al. (2011) determined in their study that Saragassum cinereum methanol extracts showed high activity against $S$. typhi, K. pneumoniae, $P$. aeurginosa and $S$. aureus strains.

The high activity of the MICs and MBCs of macroalgae extracts against bacteria which were identified in the present study, are consistent with the results of that were previously reported in other studies (Banaigs et al., 1983; Smith et al., 2002; Kamenarska et al. 2009; Osman et al., 2010; Ertürk and Taş, 2011; Salem et al., 2011; Ghannadi et al., 2013; Oumaskour et al., 2013; Yegdaneh et al., 2013; Al Zahrani et al., 2014; Parsaeimehr and Lutzu 2016; Martins et al. 2018; Arguelles et al., 2019; Eliuz et al., 2019; El-Sheekh et al.,2020; Mirzadeh et al., 2020; Arguelles 2021; Cabral et al., 2021;).

Data from previous studies reveals that these natural biologically active compounds in algae are an important resource for human health. Several researchers investigated the antimicrobial potential of seaweeds detected in different regions of our country (Demirel et al., 2009; Battu et al., 2011, Tuney et al., 2006; Gümüş et al., 2018; Güner et al., 2019). In this study, significant levels of antimicrobial effects were observed in macroalgae extracts. Similar results in this study were reported by JingWen and Wei-ci 1984, Yegdaneh et al. 2016, Zouaoui and Ghalem 2017 and Negara et al. 2020 have also been determined.

Previous studies reported that red, brown and green macroalgae extracts showed antimicrobial properties against various microorganisms and this antimicrobial activity was found in macroalgae extracts due to the presence of bioactive compounds also known as secondary metabolites. Secondary metabolites that differ regarding their species are defined as molecules that are responsible for antimicrobial activity (Bourgougnon and Stiger Pouvreau, 2012). Secondary metabolites demonstrated that these active compounds produced by macroalgae have antiviral, antimicrobial, antithrombic, anticoagulant and cell growth inhibitory effects on many biological activities beneficial for human health. Considering the research in this field, natural products with biological and pharmacological effect are predominantly species belonging to marine brown, red and green macroalgae (Bhadury and Wright, 2004). Studies previously reported that chemical composition and antimicrobial activity of macroalgae vary depending on different species, the region where the thalli are located, physiological and environmental (climate, region, salinity, temperature) conditions, pollution, growth conditions, harvest time and epiphytic organisms (Nagayama et al., 2002; Gümüş et al., 2018; Güner et al., 2019; Moshfegh et al., 2019; Wang et al., 2020; Silva et al., 2020; Kuda et al., 2021).

Macroalgae have been commonly used in food, medicine, pharmacy, cosmetics, feed, fertilizer and other industrial fields for a long time because they contain bioactive components. On the other hand, the antimicrobial capacity of macroalgae extracts depends on different variables such as macroalgae type, solvent, extraction method, extract concentration and the type of the microorganisms used. As a result; the influences of the antimicrobial extract, which exists in macroalgae, may replace among natural protective antimicrobial agents in different areas of the industry with the aid of further detailed studies. Hence, it is necessary to conduct the more comprehensive studies on screening of the antioxidant, antibacterial and antimicrobial activities of macroalgae.

\section{References}

Abourriche A, Charrouf M, Bennamara A, Berrada M, Chaib N, Boudouma M, Francisco C. 1999. Investigation of bioactivity of extracts from Moroccan solitary tunicate Cynthia savignyi. Journal of Ethnopharmacology, 1999. 68: 47-53. doi: https://doi.org/10.1016/S0378-8741(99)00033-1

Adrien A, Dufour D, Baudouin S, Maugard T, Bridiau N. 2017. Evaluation of the anticoagulant potential of polysacchariderich fractions extracted from macroalgae. Natural Product Research, 31: 2126-2136. doi: https://doi.org/10.1080/ .2017 .1278595

Al-Zahrani A, Al-Haj N, Omer H, Al-Judaibi A. 2014. Impact of Extracts of Marine Macroalgae on Multidrug-Resistant Bacteria. Journal of Microbiology Research, 4: 18-24. doi: https://doi.org/10.5923/s.microbiology.201401.03

Arguelles EDLR, Monsalud RG, Sapin AB. 2019. Chemical composition and in vitro antioxidant and antibacterial activities of Sargassum vulgare C. Agardh from Lobo, Batangas, Philippines. Journal of International Society for Southeast Asian Agricultural Sciences. 25(1): 112-122.

Arguelles EDLR. 2021. Evaluation of Antioxidant Capacity, Tyrosinase Inhibition, and Antibacterial Activities of Brown Seaweed, Sargassum ilicifolium (Turner) C. Agardh 1820 for Cosmeceutical Application. Journal of Fisheries and Environment, 45(1): 64-77.

Banaigs B, Francisco C, Gonzalez E, Fenical W. 1983. Diterpenoid metabolites from the marine alga Cystoseira elegans. Tetrahedon, 39: 629-638. doi: https://doi.org/10.1016/S0040-4020(01)91838-1

Bansemir A, Blume M, Schroder S, Lindequist U. 2006. Screening of cultivated seaweeds for antibacterial activity against fish pathogenic bacteria. Aquaculture, 252: 79-84. doi: https://doi.org/10.1016/j.aquaculture.2005.11.051

Battu GR, Ethadi S, Prayaga Murthy P, Praneeth VS, Rao M. 2011. In vitro antibacterial activity and preliminary phytochemical screening of three algae from Visakhapatnam Coast, Andhra Pradesh India. International Journal of Pharmacy and Pharmaceutical Sciences, 3(4): 399-401.

Bhadury P, Wright CP. 2004. Exploitation of marine algae: biogenic compounds for potential antifouling application. Planta, 219: 561-578. doi: https://doi.org/10.1007/s00425004-1307-5

Bhowmick S, Mazumdar A, Moulick A, Adam V. 2020. Algal metabolites: An inevitable substitute for antibiotics. Biotechnology Advances, 43: 107571. doi: https://doi.org/10.1016/j.biotechadv.2020.107571

Biris-Dorhoi ES, Michiu D, Pop CR, Rotar AM, Tofana M, Pop OL, Socaci SA, Farcas AC. 2020. Macroalgae-A Sustainable Source of Chemical Compounds with Biological Activities. Nutrients, 12: $3085 . \quad$ doi: https://doi.org/10.3390/nu12103085

Blunt JW, Copp BR, Hu WP, Munro MHG, Northcote PT, Prinsep, MR. 2007. Marine natural products. Natural Product Reports, 24: 31-86. doi: https://doi.org/10.1039/B603047P

Bourgougnon N, Stiger-Pouvreau V. 2012. Chemodiversity and bioactivity within red and brown macroalgae along the French coasts, metropole and overseas departements and territories. 58-105 pp. In: Kim, S-K. (Eds.), Handbook of Marine Macroalgae. JohnWiley \& Sons, Ltd., 567 p. 
Bory de Saint-Vincent JBGM. 1832. Hydrophytes. In: Expédition scientifique de Morée. Section des sciences physiques. Tome III. 2e partie. Botanique, pp. 1-367 [368]. (Bory de Saint-Vincent, J.B.G.M Eds), pp. 316-337. Paris \& Strabourg: Chez F. G. Levrault, imprimeur-libraire, rue de la Harpe, n. 81; même maison, rue des Juifs, n. 33 (Strasbourg, imprimerie de Levrault).

Braña AF, Fiedler HP, Nava H, González V, Sarmiento-Vizcaíno A, Molina A, Acuña JL, García LA, Blanco G. 2015. Two Streptomyces Species Producing Antibiotic, Antitumor, and Anti-Inflammatory Compounds Are Widespread Among Intertidal Macroalgae and Deep-Sea Coral Reef Invertebrates from the Central Cantabrian Sea. Microbial Ecology, 69: 512524. doi: https://doi.org/10.1007/s00248-014-0508-0

Cabral EM, Oliveira M, Mondala JRM, Curtin J, Tiwari BK, GarciaVaquero M. 2021. Antimicrobials from Seaweeds for Food Applications. Marine Drugs, 19(4): 211. doi: https://doi.org/10.3390/md19040211.

Chew YL, Lim YY, Omar M, Khoo KS. 2008. Antioxidant activity of three edible seaweeds from two areas in South East Asia. LWT-Food Science and Technology, 41(6): 1067-1072. doi: https://doi.org/10.1016/j.lwt.2007.06.013

Chiheb I, Riadi H, Martine -Lopez J, Dominguez-Seglar JF, Gomez Vidal JA, Bouziane H, Kadiri M. 2009. Screening of antibacterial activity in marine green and brown macroalgae from the coast of Morocco. African Journal of Biotechnology, 8(7): 1258-1562.

Cox S, Abu-Ghannam N, Gupta S. 2010. An assessment of the antioxidant and antimicrobial activity of six species of edible Irish seaweeds. International Food Research Journal, 17: 205220.

CLSI. 2018. Methods for Dilution Antimicrobial Susceptibility Tests for Bacteria That Grow Aerobically-11th edition. CLSI standard M07. In. Wayne, PA: Clinical and Laboratory Standards Institute.

Cornish ML, Garbary DJ. 2010. Antioxidants from macroalgae: potential applications in human health and nutrition. Algae, 25(4): 155-171. doi: https://doi.org/10.4490/algae.2010.25. 4.155

Dahms HU, Dobretsov S. 2017. Antifouling Compounds from Marine Macroalgae. Marine Drugs, 15(9): 265. doi: https://doi.org/10.3390/md15090265

Demirel Z, Yilmaz-Koz FF, Karabay-Yavasoglu U, Ozdemir G, Sukatar A. 2009. Antimicrobial and Antioxidant Activity of Brown Algae from the Aegean Sea. Journal of the Serbian Chemical Society, 74: 619-628. doi: https://doi.org/10.2298/ JSC0906619D

Divya CV, Devika V, Asha KRT, Bharat G. 2011. Antimicrobial Screening of the Brown Algae Sargassum cinereum. Journal of Pharmacy Research, 4(2): 420-421.

Dulger B, Hacioglu N, Erdugan H, Aysel H. 2009. Antimicrobial Activity of Some Brown Algae from Turkey. Asian Journal of Chemistry, 21(5): 4113-4117.

Eliuz E, Börekçi N, Ayas D. 2019. The Antimicrobial Activity of Enteromorpha sp. Methanolic Extract and Gelatin Film Solution Against on Some Pathogens. Marine Science and Technology Bulletin, 8(2): 58-63. doi: https://doi.org/ 10.33714/masteb.640614

Ellis J, Solander D. 1786. The natural history of many curious and uncommon zoophytes, pp. [i]-xii, [1]-208, 63 pls. London: Printed for Benjamin White and Son, at Horace's Head, FleetStreet and Peter Elmsly, in the Strand.

El Shafay SM, Ali SS, El-Sheekh MM. 2016. Antimicrobial activity of some seaweed's species from red sea, against multidrug resistant bacteria. The Egyptian Journal of Aquatic Research, 42: 65-74. doi: https://doi.org/10.1016/j.ejar. 2015.11.006

El-Sheekh MM, Mousa ASH, Farghl AAM. 2020. Antibacterial efficacy and phytochemical characterization of some marine brown algal extracts from the red sea, Egypt. Romanian Biotechnological Letters; 25(1): 1160-1169. doi: https://doi.org/10.25083/rbl/25.1/1160.1169

Ertürk Ö, Taş B. 2011. Antibacterial and Antifungal Effects of Some Marine Algae. Kafkas Üniversitesi Veteriner Fakültesi Dergisi, 17: 121-124.
Ghannadi A, Plubrukarn A, Zandi K, Sartavi K, Yegdaneh A. 2013. Screening for antimalarial and acetylcholinesterase inhibitory activities of some Iranian seaweeds. Research in pharmaceutical sciences, 8(2): 113-118. PMID: 24019820; PMCID: PMC3764674

Glombitza KW. 1979. Antibiotics from algae. Hoppe I.L.A., Ed., Marine Algae in Pharmaceutical Science, Waiter de Gruyter, Berlin, New York, 303f.

Gouveia V, Seca AML, Barreto MC, Pinto DCGA. 2013. Di- and sesquiterpenoids from Cystoseira genus: Structure, intramolecular transformations and biological activity. Mini Reviews in Medicinal Chemistry, 13: 1150-1159. doi: https://doi.org/10.2174/1389557511313080003

Gümüş B, Ünlüsayın M, Gümüş E. 2018. A review on antimicrobial properties of marine macroalgae extracts. Ege Journal of Fisheries and Aquatic Sciences, 35(3): 343-351. doi: https://doi.org/10.12714/egejfas.2018.35.3.15

Guner A, Koksal C, Erel SB, Kayalar H, Nalbantsoy A, Sukatar A, Karabay Yavasoglu, NU. 2015. Antimicrobial and antioxidant activities with acute toxicity, cytotoxicity and mutagenicity of Cystoseira compressa (Esper) Gerloff \& Nizamuddin from the coast of Urla (İzmir, Turkey). Cytotechnology, 67: 135-143. doi: https://doi.org/10.1007/s10616-013-9668-x

Guner A, Nalbantsoy A, Sukatar A, Karabay Yavaşoğlu, NÜ. 2019. Apoptosis-inducing activities of Halopteris scoparia L. Sauvageau (Brown algae) on cancer cells and its biosafety and antioxidant properties. Cytotechnology, 71: 687-704. doi: https://doi.org/10.1007/s10616-019-00314-5

Guven KC, Coban B, Ozdemir O. 2020. Pharmacology of marine macroalgae. Encyclopedia of Marine Biotechnology, 1: 585615. doi: https://doi.org/10.1002/9781119143802.ch20

Hans N, Malik A, Naik S. 2021. Antiviral activity of sulfated polysaccharides from marine algae and its application in combatin g COVID-19: Mini review. Bioresource Technology Reports, 13: 100623. doi: https://doi.org/ 10.1016/j.biteb.2020.100623

Jaswir I, Monsur HA. 2011. Anti-inflammatory compounds of macro algae origin: A review. Journal of Medicinal Plants Research, 5: 7146-7154. doi: https://doi.org/10.5897/ JMPRX11.018

Jegan S, Raj A, Chandrasekaran M, Vencatesalu V. 2019. AntiMRSA activity of Padina tetrastromatica, Padina gymnospora from guft of mannar biosphere. World Scientific News, 115: $15-26$.

Jing-Wen M, Wei-ci T. 1984. Screening for antimicrobial activities in marine algae from the Qingdao coast, China. Hydrobiologia, 116:517-520. doi: https://doi.org/10.1007/ BF00027736

Kamenarska Z, Serkedjieva J, Najdenski H, Stefanov K, Tsvetkova I, Dimitrova-Konaklieva S. et al. 2009. Antibacterial, antiviral, and cytotoxic activities of some red and brown seaweeds from the Black Sea. Botanica Marina, 52(1): 80-86. doi: https://doi.org/10.1515/BOT.2009.030

Kazlowska K, Hsu T, Hou CC, Yang WC, Tsai GJ. 2010. Antiinflammatory properties of phenolic compounds and crude extract from Porphyra dentate. Journal of Ethnopharmacology, 128(1): 123-130. doi: https://doi.org/10.1016/j.jep.2009.12.037

Kuda T, Nishizawa M, Toshima D, Matsushima K, Yoshida S, Takahashi H, Kimura B, Yamagishi T. 2021. Antioxidant and anti-norovirus properties of aqueous acetic acid macromolecular extracts of edible brown macroalgae. LWT, 141: 110942. doi: https://doi.org/10.1016/j.lwt.2021.110942 Manivannan K, Karthikai devi G, Anantharaman P, Balasubramanian T. 2011. Antimicrobial potential of selected brown seaweeds from vedalai coastal waters, Gucf of Mannar. Asian Pacific Journal of Tropical Biomedicine, 1(2): 114-120. doi: https://doi.org/10.1016/S2221-1691(11)600075 
Martins RM, Nedel F, Guimarães VBS, da Silva AF, Colepicolo P, Pereira CMP, Lund RG. 2018. Macroalgae extracts from Antarctica have antimicrobial and anticancer potential. Frontiers in Microbiology, 9:412. doi: https://doi.org/ 10.3389/fmicb.2018.00412

Mayer AMS, Rodríguez AD, Berlinck RGS, Fusetani N. 2011. Marine pharmacology in 2007-8: Marine compounds with antibacterial, anticoagulant, antifungal, anti-inflammatory, antimalarial, antiprotozoal, antituberculosis, and antiviral activities; affecting the immune and nervous system, and other miscellaneous mechanisms of action. Comparative Biochemistry and Physiology Part C: Toxicology \& Pharmacology, 153(2): 191-222. doi: https://doi.org/ 10.1016/j.cbpc.2010.08.008

Matanjun P, Mohamed S, Mustapha NM, Muhammad K, Ming CH. 2008. Antioxidant activities and phenolics content of eight species of seaweeds from north Borneo. Journal of Applied Phycology, 20(4): 367-373. doi: https://doi.org/ 10.1007/s10811-007-9264-6

Mickymaray S, Alturaiki W, Al-Aboody MS, Mariappan P, Rajenderan V, Alsagaby SA, Kalyanasundram U, Alarfajj AA. 2018. Anti-bacterial efficacy of bacteriocin produced by marine Bacillus subtilis against clinically important extended spectrum beta-lactamase strains and methicillin-resistant Staphylococcus aureus. International Journal of Medical Research \& Health Sciences, 7(2): 75-83.

Mirzadeh M, Arianejad MR, Khedmat L. 2020. Antioxidant, antiradical, and antimicrobial activities of polysaccharides obtained by microwave-assisted extraction method: A review. Carbohydrate Polymers, 229: 11542. doi: https://doi.org/10.1016/j.carbpol.2019.115421

Mohamed S, Hashim SN, Rahman HA. 2012. Seaweeds: A sustainable functional food for complementary and alternative therapy. Trends in Food Science \& Technology, 23(2): 83-96. doi: https://doi.org/10.1016/j.tifs.2011.09.001

Moshfegh A, Salehzadeh A, Sadat Shandiz SA. Shafaghi M, Naeemi AS, Salehi S. 2019. Phytochemical Analysis, Antioxidant, Anticancer and Antibacterial Properties of the Caspian Sea Red Macroalgae, Laurencia caspica. Iranian Journal of Science and Technology, Transactions A: Science, 43(1): 49-56. doi: https://doi.org/10.1007/s40995-017-0388-5

Musale AG, Raja KK, Ajit S, Dasgupta S. 2020. Marine Algae as a Natural Source for Antiviral Compounds. AIJR Preprints Series: Coronavirus. doi: https://doi.org/10.21467/ preprints. 38

Nagayama K, Iwamura Y, Shibata T, Hirayama I, Nakamura T. 2002. Bactericidal activity of phlorotannins from the brown alga Ecklonia kurome. Journal of Antimicrobial Chemotherapy, 50(6): 889-893. doi: https://doi.org/ $10.1093 / \mathrm{jac} / \mathrm{dkf} 222$

Negara BFSP, Oktoviani, Nugraheni E, Kusuma AB, Kontesa R, Putra ED, Siallagan D, Herliany NE, Purnama D. 2020. The Utilization of Seaweeds as An Inexpensive Source of New Drugs Agent. IOP Conf. Series: Earth and Environmental Science ,593(1): 012033. doi: https://doi.org/10.1088/1755$1315 / 593 / 1 / 012033$

Osman MEH, Abushady AM, Elshobary ME. 2010. In vitro screening of antimicrobial activity of extracts of some macroalgae collected from Abu-Qir Bay Alexandria, Egypt. African Journal of Biotechnology, 9(42): 7203-7208.

Oumaskour K, Boujaber N, Etahiri S, Assobhei O. 2012. Screening of antibacterial and antifungal activities in green and brown algae from the coast of Sidi Bouzid (El Jadida, Morocco). African Journal of Biotechnology, 11(104): 16831-16837.

Oumaskour K, Boujaber N, Etahiri S, Assobhei O. 2013. Antiinflammatory and antimicrobial activities of twenty-three marine red algae from The Coast of Sidi Bouzid (El JadidaMorocco). International Journal of Pharmacy and Pharmaceutical Sciences, 5: 145-149.
Parsaeiemhr A, Lutzu GA. 2016. Algae as a novel source of antimicrobial compounds:Current and future perspective. In: Antibiotic Resistance. Mechanisms and New Antimicrobial Approaches - 1st edition, Eds: K. Kon, M. Rai. Academic Press.

Paul VJ, Puglisi MP. 2004. Chemical mediation of interactions among marine organisms. Natural Product Reports, 21(1): 189-209. doi: https://doi.org/10.1039/B302334F

Pérez MJ, Falqué E, Domínguez H. 2016. Antimicrobial Action of Compounds from Marine Seaweed. Marine drugs, 14(3): 52. doi: https://doi.org/10.3390/md14030052

Rhimou B, Hassane R, Jose M, Nathalie B. 2010. The antibacterial potential of the seaweeds (Rhodophyceae) of the Strait of Gibraltar and the Mediterranean Coast of Morocco. African Journal of Biotechnology, 9(38): 6365-6372.

Rizvi MA, Shammel M. 2004. Studies on the bioactivity and Elementology of marine algae from the Coast of Karachi, Pakistan. Phytotherapy Research: An International Journal Devoted to Pharmacological and Toxicological Evaluation of Natural Product Derivatives, 18(11): 865-872. doi: https://doi.org/10.1002/ptr.1441

Salem WM, Galal H, Nasr El-Deen F. 2011. Screening for antibacterial activities in some marine algae from the red sea (Hurghada, Egypt). African Journal of Microbiology Research, 5(15): 2160-2167. doi: https://doi.org/10.5897/ AJMR11.390

Salvador N, Garreta AG, Lavelli L, Ribera MA. 2007. Antimicrobial activity of Iberian macroalgae. Scientia Marina, 71(1): 101-113. doi: http://dx.doi.org/10.3989/ scimar.2007.71n1101

Sauvageau C. 1912. A propos des Cystoseira de Banyuls et Guéthary. Bulletin de la Station biologique d'Arcachon, 14: 133-556.

Seca AML, Pinto D. 2018. Overview on the Antihypertensive and Anti-Obesity Effects of Secondary Metabolites from Seaweeds. Marine Drugs, 16(7): 237. doi: https://doi.org/10.3390/md16070237

Silva A, Silva SA, Carpena M, Garcia-Oliveira P, Gullón P, Barroso MF, Prieto MA, Simal-Gandara J. 2020. Macroalgae as a source of valuable antimicrobial compounds: Extraction and applications. Antibiotics, 9(10): 642. doi: https://doi.org/10.3390/antibiotics9100642

Smith JE, Hunter CL, Smith CM. 2002. Distribution and reproductive characteristics of nonindigenous and invasive marine algae in the Hawaiian Islands. Pacific Science, 56(3): 299-315. doi: https://doi.org/10.1353/psc.2002.0030

Smit AJ. 2004. Medicinal and pharmaceutical uses of seaweed natural products: A review. Journal of Applied Phycology, 16(4): 245-262. doi: https://doi.org/10.1023/B:JAPH. 0000047783.36600.ef

Tambekar DH, Patil RV, Pawar AL. 2011. Studies on Methanotrophs from Lonar Lake. Journal of Research in Biology. 3: 230-236.

Tuney I, Cadirci BH, Unal D, Sukatar A. 2006. Antimicrobial activities of the extracts of marine algae from the coast of Urla (Izmir Turkey). Turkish Journal of Biology, 30(3): 171 -175.

Wang C, Lu Y. Cao, S. 2020. Antimicrobial compounds from marine actinomycetes. Archives of Pharmacal Research, 43: 677-704. doi: https://doi.org/10.1007/s12272-020-01251-0

Watson SB, Cruz-Rivera E. 2003. Algal chemical ecology: an introduction to the special issue. Phycologia, 42(4): 319-323. doi: https://doi.org/10.2216/i0031-8884-42-4-319.1

Yamada Y. 1931. Notes on some Japanese algae II. Journal of the Faculty of Science, Hokkaido Imperial University 1: 65-76, 3 figs, plates XVI-XX.

Yegdaneh A, Putchakarn S, Yuenyongsawad S, Ghannadi A, Plubrukarn A. 2013. 3-oxoabolene and 1-oxocurcuphenol, aromatic bisabolanes from the sponge Myrmekioderma sp. Natural Product Communications, 8(10): 1355-1357. doi: https://doi.org/10.1177/1934578X1300801002 
Yegdaneh A, Ghannadi A, Dayani L. 2016. Chemical constituents and biological activities of two Iranian Cystoseira species. Research in Pharmaceutical Sciences, 11(4): 311-317. doi: https://doi.org/10.4103/1735-5362.189 307.

Yuan YV, Carrington MF, Walsh NA. 2005. Extracts from dulse (Palmaria palmata) are effective antioxidants and inhibitors of cell proliferation in vitro. Food and Chemical Toxicology, 43(7): 1073-1081. doi: https://doi.org/10.1016/j.fct. 2005.02.012
Zouaoui B, Ghalem BR. 2017. The Phenolic Contents and Antimicrobial Activities of Some Marine Algae from the Mediterranean Sea (Algeria). Russian Journal of Marine Biology, 43(6): 491-495. doi: https://doi.org/10. $1134 / \mathrm{S} 1063074017060128$ 